\title{
Conniving Women and Superannuated Coquettes: Travestis and Caractères in the Early Modern French Theatre
}

In his 1651 Roman comique that depicts the adventures of an itinerant theatrical troupe in the French provinces, Paul Scarron describes a conventional representation of older female characters in French comedy: 'Au temps qu'on était réduit aux pièces de Hardy, il [La Rancune] jouait en fausset et, sous les masques, les roles de nourrice' [In the period when troupes were reduced to the plays of Hardy, he played in falsetto, wearing a mask, the roles of the nurse]. ${ }^{1}$ The nourrice was a character type from Roman and Italian Renaissance comedy, often an entremetteuse or go-between as well as a confidant. Juliet's Nurse in Romeo and Juliet, although she participates in a story that ends tragically, is an essentially comic character and a familiar example from the English repertory.

La Rancune, an actor of the second rank, also played confidents, ambassadors, kidnappers, and assassins. This mixed emploi - confidents et nourrices - was not an unusual line of business for an actor in the early years of the seventeenth century. A comparable emploi at the end of that century would be known as confidentes et caractères. The difference is that the former was an emploi for men while the latter was for women. Female character roles became more and more important in the last decades of the seventeenth century, when comedy dominated the Paris repertory and the bourgeoisie dominated the Paris theatre audience. When the professional theatre was established in Paris in the 1630s, no women specialized in comic character roles; by the end of that century, the troupe of the Comédie-Française included Mlles Desbrosses, Godefroy, Champvallon, and Du Rieu in the emploi of caractères. The transition from men en travesti to women playing a variety of character roles is the subject of this study.

Women played only certain sorts of roles when they began to act professionally in France in the middle of the sixteenth century. ${ }^{2}$ By the last quarter of the sixteenth century women were playing all or most of the female 
roles in tragedy, possibly including confidantes and mères, but in tragicomedy, comedy, pastoral, and farce at least some women did not play or refused to play older women's roles, especially nourrices and entremetteuses. After 1630 or so, playwrights increasingly shunned the nourrice in favor of the suivante, a younger confidante, played by a woman. Molière in the 1660s and 1670s, however, still used male actors en travesti for older female roles - Madame Pernelle, Madame de Sotenville, Madame Jourdain, and even the leading role of Philaminte - although it was also Molière who late in his career entrusted several important characters to Mlle La Grange, the first true character actress in the French theatre.

Who played what in the early years of France's professional theatre is most open to question when the subject is farce. We know that an actress named Marie Ferré signed a contract in 1545 agreeing to perform in farce, but the contract is silent on the subject of what sorts of roles she might have played. We also know that an actress at the end of the century was praised for refusing to perform in farce. Farce, however, may well have been what actually determined which roles were performed by women and which were reserved for men.

Scholars assume that most of the hundreds of secular farces that were published and became available to theatrical troupes in the first sixty years of the sixteenth century predated their publication. ${ }^{3}$ It seems fair to accept the usual conclusion that most were written or written down late in the fifteenth century when women were not acting professionally and men were playing all the female roles. Women did act, however, by the time many of the farces were published.

A farce is neither a sottie nor a moralité. Unlike many moralités, farces are short plays with only a few characters, most of which are drawn from 'le petit peuple'. Moralités have allegorical characters; farces usually do not. A farce often includes foolish characters, naifs, but it usually does not include sots, characters always found in sotties and often simply known as 'Premier Sot' or 'Second Sot' or 'Mère Sot'. Sotties and moralités were performed by law clerks and law students or by confraternities and sociétés joyeuses, organizations to which women did not belong.

One obvious element that distinguishes farce is the centrality of domestic and spousal disputes and discord. The first purpose of farce is to arouse laughter, and while farce may display a satiric though clichéd attitude toward the gentry and the clergy, it is more likely to focus on the bedroom, the market stall, and the neighbour's business. As a result of this focus, female 
characters are centrally important to farce as they are not to sotties or moralités. A considerable range of such female roles exists: aggressive market women, entremetteuses, mothers who dominate their badins, their idiot sons, and shrews who dominate their miserable husbands. These female characters for the most part are not sexually active or only peripherally so, and many are middle-aged or older. Farce also includes the rare loving wife or enabling wife, but these are dwarfed by the number of sexually dissatisfied wives who have taken or want to take lovers. Farce also has rather a lot of chambrières, female servants, who are looking for love in many of the wrong places. Bernard Faivre calls such wife and servant figures femmes gourmandes d'amour, women greedy for love, and claims that at least seventy of the plays among the 176 he defines as farces rely essentially on some sexual intrigue involving these female characters. ${ }^{4}$

In the fifteenth century, men played these femmes gourmandes. Female roles in the first category - the aggressive fishwives, the old mothers, the go-betweens, and the dominating shrews - may well have continued to be a male emploi through the sixteenth, while female roles defined by sexuality could have passed into the possession of actresses. If they did, then audiences - who evidently had a hard time distinguishing between onstage and offstage behavior - can perhaps be forgiven for thinking that theatrical women were somewhat louche. ${ }^{5}$ In 1634, when women were performing in farce, Mlle de Beausoleil, an actress in Georges de Scudéry's La comédie des comédiens, notes that,

c'est une erreur où tombe presque tout le monde, pour ce qui regarde les femmes de nostre profession, car ils pensent que la farce est l'image de nostre vie, \& que nous ne faisons que representer ce que nous pratiquons en effect, ils croient que la femme d'un de vous autres, l'est indubitablement de toute la Troupe; \& s'imaginant que nous sommes un bien commun, comme le Soleil ou les Elemens. ${ }^{6}$

[almost everyone falls into error regarding women of our profession, for they think that farce is the image of our life, and that we only perform what we otherwise practice. They think that the wife of one of you is indubitably the wife of all the Troupe, imagining that we are common property like the Sun or the Elements.]

Unlike farce, comedy developed slowly in Renaissance France, and almost no evidence survives regarding who produced it or how it was performed. From the first 'humanist' comedy, Étienne Jodelle's Eugène in 1552, to the 
three final comedies of Larivey in 1611, only some twenty texts were published. ${ }^{7}$ A few of these comedies were performed during the heyday of the Pléiade, either at court or at a college where all roles would have been played by male actors. The word comédie creates a problem when the subject is professional performance, since it means both a play and a comic play. There are many references to performances of comédies by itinerant troupes in the sixteenth century but no way of knowing which genre is meant. ${ }^{8}$

Of these twenty or so published plays, some are translations of Roman plays, like Baï's Le brave, and some are near translations of sixteenth-century Italian commedie erudite, like all nine of Larivey's. This reliance on Latin and neo-Latin sources restricts women's roles. As Madeleine Lazard notes, although the character of the jeune fille is usually important to the plot, she makes only rare appearances on-stage. ${ }^{9}$ Other female character types abound - servantes, mères, courtisanes, entremetteuses, faithless wives, nourrices - but also perform relatively minor roles, most of which can safely be assigned to male actors performing en travesti. The young girls, the faithful and faithless young wives, and the courtesans could, at least if the circumstances of the troupe permitted, have been played by women. There are seventy female characters in the plays analyzed by Lazard, approximately three per play, which suggests that a professional troupe with two actresses the norm until the 1630s - playing roles where youth and/or sexuality are indicated and one actor with a specialty in travestis could include most or all of these plays in its repertory. However, given the few examples of comedy that exist and the lack of specific information about their performance, it would be foolhardy to make any definite claims. Comedy continued to be a meagre genre in the second decade of the seventeenth century, and the pickings are similarly slim until 1629-30 when Corneille's Mélite, first performed by the troupe of Montdory, and Rotrou's Bague de l'oubly, performed at the Hôtel de Bourgogne, reintroduced comedy to the Paris stage.

Pierre Corneille claims to have put a stop to travesti in comedy in the early 1630s. In his Examen of his early comedy La galerie du palais, afterthoughts thirty years after the first performance, he writes:

Le Personnage de Nourrice, qui est de la vieille Comédie, et que le manque d'Actrices sur nos Théâtres y avait conservé jusqu'alors, afin qu'un homme le pût représenter sous le masque, se trouve ici métamorphosé en celui de Suivante, qu’une femme représente sur son visage. ${ }^{10}$ 
[The Character of the Nurse, from the old Comedy, and which the lack of Actresses on our Stages had conserved until then, so that a man could play them in a mask, here finds itself metamorphosed into that of a Suivante, that a woman plays barefaced.]

This claim, often uncritically accepted by scholars of the French theatre, is just the least bit self-serving. Corneille, in fact, was not the first to use the term 'Suivante' to designate a lady's maid or a companion, normally a character who serves as a confidant and/or messenger for the jeune fille or jeune femme, now a much more active participant in her own fate than was the victimized young woman of earlier comedy. ${ }^{11}$

His comment does call attention to one of the ways in which the new comedy of the 1630s - plays by Rotrou and Claveret as well as Corneille begins to separate itself from its Roman, Italian, and Spanish antecedents and to reflect French, especially Parisian, society. Characters such as the nourrice, the courtisane, and the maquerelle, with their long-established stock behaviors, were no longer appropriate to the modern urban society reflected in the plays. Not that these characters disappeared entirely. Corneille's first suivante, for instance, is in almost every way except her character designation just another nourrice, an elderly go-between, but apparently one played by an actress rather than a travesti actor. The character in Corneille's third play La suivante is actually a companion to the heroine, of similar age and family background though poor. She was undoubtedly played by one of the troupe's two actresses, either Mlle Le Noir or Mlle Villiers. We do not know who played the suivante in La galerie du palais and several other small vieille roles in Corneille's early comedies. Farce, however, continued to use men in certain women's roles. An anonymous print featuring Turlupin and Gros Guillaume shows a bride, resigned and bewreathed, riding to her wedding on a donkey between two older women, both clearly men in women's clothes, perhaps a mother and a nourrice.

Corneille is undoubtedly right that the lack of actresses enabled travest $i$ acting, but other factors were in play as well. Actresses did not like to play older women's roles, which may in part account for the fact that after the 1630s few were written. An actress who originated an ingenue or première role retained that role until she retired; she did not dwindle to mothers and maiden aunts. As Chappuzeau noted of actresses later in the century: 'comme il n'y a une qui ne soit bien aise de passer toujours pour jeune, elles ne s'empressent pas beaucoup à representer des Sisigambis' [as there is not 
one who is not happy to pass as always young, they do not rush to perform the Sisigambis]. ${ }^{12} \mathrm{~A}$ tragic emploi did develop known as mères et reines, which included such important roles as Medea and Agrippine and appealed to some aging tragedy premières, but older female roles in comedy remained rare.

Another advantage of travesti acting that may have been hard to give up is that it can be innately comic. While a man playing a nourrice or a confidente in tragedy would avoid calling attention to the gender disparity, in comedy he could rely on it for effect. A good example of this is the play Alizon, published by its pseudonymous author L.C. Discret in 1637. Whether or not it was performed professionally - and the author would seem to suggest it was not - it was probably written in the hope that the title role would go to an actor known as Alizon who played a character that crops up from time to time in plays of the $1620 \mathrm{~s}$ and $1630 \mathrm{~s} .{ }^{13}$ The existence of a travesti actor who played as Alizon is confirmed by a list of the actors at the Hôtel de Bourgogne published in Renaudot's Gazette of 15 December 1634; the men include Bellerose, Belleville, L'Espy, Le Noir, Guillot-Gorju, Saint-Martin, Jodelet, La France or Jaquemin Jadot, and Alizon. ${ }^{14}$ An engraving of the period by Huret and Mariette also shows a clearly masculine Alizon in company with Michau, Boniface, and Philipin.

Alizon or Alison or Alix or even Alice is a name that recurs in farce to signal an older woman with lusty appetites. Even Chaucer's Wife of Bath is named Alison. Discret's Alizon Fleurie, described in the cast of characters as vieille, is certainly lusty. She has three suitors: a peddler, a superannuated soldier (he claims to be eighty), and an elderly bourgeois named Monsieur Karolu. She also has three daughters, and the daughters have three suitors. The play mixes old and new elements; here the farce vieille, rising in social status, remains unabashedly bawdy although inserted into a kind of bourgeois comedy of manners filled with local references and local colour.

The widow Fleurie mourns her departed husband, Ulysses to her Penelope, even though he was so jealous that he kept her locked inside where she saw green fields only in an old picture hanging on the wall. She now enjoys a new relationship with her bourgeois suitor Monsieur Karolu (probably from carolus, a small coin, so Mr. Smallchange or Mr. Pennyfarthing), whose enthusiastic kissing both arouses her feu and lifts her coif off her head. This kind of knock-about farce, its humour heavily based on the incongruous casting of a man as Madame Fleurie, is tempered by the action of the three pretty, precious, and proper daughters. Though by birth daughters of the people, they are courted during the play by three young gentlemen whom 
they meet during a boat excursion and picnic organized by Monsieur Karolu. The picnic is enlivened by a number of songs, including one performed by Alizon:

J'ay bien le meilleur homme

Qui soit dedans Paris,

En tous lieux il me nomme

Sa gentille Cloris.

Nous pissons dans mesme pot,

Nous nous baisons à gogo,

Nous chantons tan-tire-li-ra-lire

Sans jamais nous dire mot.

[I had the very best of all the men / who've been in Paris. / I was the one that he would call / his lovely, darling Cloris. / We pissed in the same pot, / we kissed a go go, / we sang tan-ta-ra-ta-ra, / but never said a word, oh.]

Tousjours l'un contre l'autre

L'on void nos deux manton,

Et souvent il se veautre

Dessus mes blancs tetons.

Nous pissons, etc.

[Lips and tongues were pressed together, / we were as one, we were a fit, / as he wallowed in the pleasure / of my generous white tits. / We pissed, etc.]

The husband also cleaned the crotte, that special Paris muddy mixture of earth, ordures, and dung, off her underdrawers, made excellent sausages, did all the housekeeping, and never ate or drank a thing until she was satisfied (1.1). The taste for this kind of comedy was not entirely lost after 1640 . The play was republished in 1664 with a few changes to bring the Parisian context up to date but with nothing to temper the character's lively vulgarity.

The character name Alison last appears in 1647 in Paul Scarron's Les boutades de Capitan Matamore, where she is the wife of Boniface. H.C. Lancaster doubts that the play was ever performed. In the two decades between the first publication of Alizon and the return to Paris of Molière and his fellow actors in 1658, there is no evidence of men appearing in women's roles, although they must have done. A number of plays include a flirtatious older woman, a vieille coquette, or other elderly character types, but no information exists 
to tell us how they were cast. Le Vert's Docteur amoureux (1637) has a nourrice with dentures and a wig, Thomas Corneille's Dom Bertrand de Cigarral (1651) has an old maid who faints seven times a day, Tristan L'Hermite's Parasite (1653-4) features a vieille servante with a savage tongue who calls her master 'simulacre platré, antiquaille mouvante, / Squellette décharné, sépulture ambulante' [plaster simulation, jiggling piece of old junk, bag of bones, walking sepulchre]. ${ }^{15}$

Although both the Hôtel de Bourgogne and the Marais appear to have had farce troupes in the 1660s, there is no evidence of a travesti actor in either company. The actor Raymond Poisson, who played the stock role of Crispin, furnished the Hôtel with several farces, while at the Marais the actor Jean Chevalier wrote for his own character Guillot and another named Ragotin. None of these plays features older women's roles. Nor did Molière, who is often held responsible for the reintroduction of farce in the 1660s with Les précieuses ridicules, include vieilles ridicules in his early plays, even though his actor Louis Béjart later performed en travesti as Madame Pernelle in Tartuffe. Other comedies continued to include occasional vieilles, but there is no information regarding who might have played Dame Nicole, a respectable entremetteuse in Villiers's new version of Les ramonneurs, or Ruffine, a femme d'intrigue in Chappuzeau's L'avare duppé.

In 1665 , however, two theatres opened competing plays with the same title. The troupe of the Palais-Royal, where Molière and his actors had settled in 1661, opened La mère coquette by Jean Donneau de Visé on 23 October; a few days later, the Hôtel de Bourgogne countered with a play of the same title by Philippe Quinault. Both were originally successful, although Visé's version dropped out of the repertory after its second season while Quinault's continued to be performed by the Comédie-Française until 1781. Although these were by no means the first comedy mères in the French theatre, they were innovative; according to Lancaster, Visé's Lucinde 'justifies the author's pride in her as an original creation. ${ }^{16}$ Both mothers have the characteristics of the vieille coquette, but the text of Visé's version indicates that Chappuzeau was right to suggest that playwrights sometimes had to make certain adjustments to older female characters if actresses were going to be willing to play them. Indeed, the adjustments enable the hypothesis that Lucinde was played by an actress, probably the thirty-two-year-old Marquise Du Parc. Lucinde 'may be a woman in middle life, unwilling to surrender her youth and resenting her daughter's existence', as Lancaster notes. ${ }^{17}$ Lucinde, however, admits only to the age of thirty. ${ }^{18}$ 
The playwright may have been thinking of his leading lady's dislike of playing a mère when he opens the play with a verse that underscores the desirability of the character. Jacinte asks, 'Madame, d'où vous vient cette langueur mortelle? / Vous êtes, quoi que Veuve, \& jeune, \& riche, \& belle' [Madame, what's the reason for this deathly melancholy? / You are, although a Widow, young and rich and beautiful] (1.1). ${ }^{19}$ Obsessed with age and the potential loss of her appeal, Lucinde fears that in a competition with her beautiful young daughter she is certain to lose. When the daughter Belamire appears with beauty patches on her face and wearing high heels, her mother, who insists on being addressed as 'Madame' and not 'Ma Mère', forces her to remove the mouches and take off the heels. In fact, her obsessive anxiety combined with the possibility that the actress playing the role was still relatively young and beautiful makes the play more of a character study than a comic attack on a vieille ridicule.

Perhaps Quinault's version survived for many years as a standard of the comic repertory because it is a more skillful if less original play with a less obsessed but more ridiculous central character. Although Ismene, too, alleges that she is thirty, her claim to youthful beauty is not validated by another character. Indeed, her servante-suivante Laurette tries to soothe her by saying that 'on peut être belle encore à quarante ans' [one can still be beautiful at forty] (2.2) ${ }^{20}$ In addition, a servant attributes her delayed entrance to the fact that 'Madame is making up her face'. Laurette tells him to shut his blabbermouth, making up one's face being a dead giveaway in this period that one is older than one wishes to be thought. Ismene herself admits to the 'mille soins tâcher de rétablir / Ce que de mes appas l'âge peut affoiblir' [the thousand beauty treatments to try to bring back / the attractions that age has weakened] (1.2).

Although Ismene's ruses are so blatant and opportunistic that they only increase her absurdity, she is much wilier than Lucinde. Assuring Acante, the young man she wants to steal from her daughter, that Isabelle speaks of him only with anger and hatred, she pretends to sympathize while arguing for the constancy of an older woman's love:

La jeunesse, Monsieur, n'est que légéreté;

Au sortir de l'enfance une ame est peu capable

De la solidité d'un amour raisonnable,

Un coeur n'est pas encor assey fait à seize ans,

Et le grand art d'aimer veut un peu plus de tems. 
C'est après les erreurs où la jeunesse engage,

Vers trente ans, c'est-à-dire, environ à mon âge,

Lorsqu'on est de retour des vain amusements

Qui détournent l'esprit des vrais attachemens.

[Youth, Monsieur, lacks substance; / as childhood ends, a soul is not yet capable / of the solidity of love based on reason. / A heart is not mature enough at sixteen, / and the great art of loving needs a little more time. / It is only after the errors of youth, / towards thirty, that is to say, around my age, / when one turns away from vain amusements, / that the mind is drawn to true attachments.]

Unlike her predecessor Lucinde, who seems to be actually suffering from her obsession with age, Ismene is unsympathetic and ridiculous. She, not Lucinde, offers a model for the vieille coquette, one of the mainstays of the vieille emploi.

Although we do not know who at the Hôtel de Bourgogne played Ismene in 1665 , there is no evidence of any travesti actor in that troupe at the time. When the Comédie-Française in 1684 made a list of the plays in its repertory and assigned actors to the various roles, the role of Ismene in Quinault's La mère coquette was given to Mlle La Grange, in my view the first actress in France to make a specialty of comic caractères. Mlle La Grange had a curious career. She was born Marie Ragueneau, the daughter of Cyprian Ragueneau, who is celebrated as a character in Rostand's Cyrano de Bergerac. Marie, known as Marotte, was born in 1639 and baptized at St-Germainl'Auxerrois. In the act of baptism her father claimed to be an 'Honourable man, pâtissier of Monsieur le Cardinal de Richelieu' ${ }^{21}$ Apparently the honourable man abandoned his pâtisserie, changed his name to L'Estang, and joined Molière's troupe in Lyon, where he died in $1654 .^{22}$ His widow and his daughter remained attached to the troupe and accompanied it back to Paris. During the first twelve years of the Molière era, 1658-70, Mlle Marotte, then a gagiste or non-sharer, was cast by Molière in only two roles in his plays, both peasant servants. Because Molière used the real names of his actors in Les précieuses ridicules (1659), historians have concluded that Marie Ragueneau played the tiny role of the servante Marotte. That Mlle Marotte also played the somewhat larger role of Georgette in L'école des femmes (1662) is substantiated by evidence from the troupe's records. ${ }^{23}$ The Première registre de La Thorillière, which documents the troupe's financial dealings in 16634 , notes payments of three livres per day to Mlle Marotte from 1 June (when 
the first reprise of L'école des femmes opened with its Critique) to 26 June. That she had been playing Georgette is certain: beginning on 29 June, three days after the final payment to her, the troupe paid for a new costume for the character. Sharers in the troupe were obliged to furnish their own costumes; non-sharers were not. Since there is no record of a daily payment to whoever wore the new costume, the role must have been assumed by a sharing member, possibly Louis Béjart, who was to play Madame Pernelle in Tartuffe and who logically could not have worn a costume sized for a woman. ${ }^{24}$ If so, this is the first known instance of Molière using a travesti actor. His roles were not necessarily gender specific; in 1684, Mlle La Grange shared Madame de Sotenville in George Dandin with M. Beauval.

Mlle Marotte might, of course, have performed in other plays in other seasons by other playwrights and received the usual three livres a day. La Thorillière's Registre exists for only two seasons, and our primary source of information about the troupe's financial dealings, the Registre of $\mathrm{La}$ Grange, does not usually include extraordinary expenses. She was, however, attached to the troupe; evidence from La Grange suggests she might have been employed as a recevreuse, or box-office manager. ${ }^{25}$ At the end of the 1659-60 season, he lists 'Mle L'Estang' as one of the women employed for 'recept et controle', i.e., box office. At the end of the 1661-2 season, however, the woman is 'Me de l'Estang', who should be the wife of the late Ragueneau dit L'Estang and not the daughter. It makes sense that 'Mme de L'Estang' worked in the box office and 'Mlle L'Estang' worked from time to time as a gagiste, but there seems no way to be certain. Ten years later, however, Mlle L'Estang originated three important roles in three of Molière's late plays: one of the sisters in Psyché, Bélise in Les femmes savantes, and the title role in La Comtesse d'Escarbagnas. ${ }^{26}$ All of these roles are significant in the creation of the caractere emploi and were played by actresses in that emploi at the Comédie-Française after 1680.

There is no way to know which actress played which sister in Psyché when it was performed for the court in January 1671, because the two actresses are listed together: 'Mlles Marotte et Boval'. If that order means anything, then Mlle Marotte would have played Aglaure, the first sister in the regular cast list, and Mlle Beauval Cidippe. The two characters are very much the same, although Aglaure is more active and aggressive and Cidippe is much given to 'me, too'. Both are 'older' than their cadette Psyché, and both deeply resent the fact that she is sought by multitudes of suitors while they languish in solitude. They are prudes and hypocrites, longing for love affairs but clinging 
to outdated notions of class and rectitude. Given Mlle Beauval's status in the troupe as a member with a full share, it seems likely that the larger and more active role of Aglaure was hers.

La Comtesse d'Escarbagnas was also part of a court festival when it was played at St-Germain-en-Laye on 2 December 1671 and reprised there for carnival in February 1672. The authors of the Notice in the new Pléiade edition of Molière's plays suggest that in the role of the Comtesse Mlle L'Estang returned to the character of the coquette she had created in Psyché, but the sisters are not nearly as coquettish as the Comtesse, who also displays many other characteristics of the vieille ridicule. ${ }^{27}$ She is clearly older than she would like to be, a provincial minor aristocrat trying to recreate the peculiar manners of Versailles with a young peasant maid and a boy named Criquet.

In Les femmes savantes, which opened in Paris on 11 March 1672, Mlle Marotte played Bélise, another hypocritical false prude who is offended by any overt advances but claims a long list of male admirers. Bélise's age is unclear since she is the sister both of Chrysale, played by Molière who was nearly fifty, and of Ariste, apparently played by Michel Baron who was nineteen, but that she is une vieille is implied. She is certainly une vieille fille, an old maid. She is distinguised by her ability to interpret whatever is said to her as a figure, something that appears to mean one thing but actually means another. This critical aptitude is her contribution to the circle of savante ladies that includes her sister-in-law and her niece. Bélise shares with the Comtesse the fantasy that an eligible young man is pursuing her.

Why Molière, after seeing this actress in occasional minor roles, suddenly began to feature her is a mystery worthy of speculation. It was only after Les femmes savantes opened successfully — and after Mlle Marotte/L'Estang married on 25 April 1672 the troupe's jeune premier La Grange - that she was finally granted a half-share in the company. Several changes in what had been since 1664 a stable troupe occurred in 1670 that may partly account for both the casting and the membership. Easter was the usual time for actor comings and goings but, unusually, the troupe added Jeanne Beauval and her husband in mid-summer. Mlle Beauval was remarkable in the range of her roles. Although she specialized in servantes and suivantes, she was also useful in tragedy, playing both confidentes and méres. ${ }^{28}$ The actress who had been featured in these roles at the Palais Royal was Madeleine Béjart, who was to die on 17 February 1672. What seems likely is that Mlle Béjart was no longer able to perform by June 1670, that Mlle Beauval took over her tragic roles and some of her comic roles, and that Mlle Marotte was available to fill 
in when needed. Now thirty-three to Mlle Beauval's twenty-three, ${ }^{29}$ Mlle Marotte could certainly have stepped into Mlle Béjart's role of Frosine, a femme d'intrigue, which she was playing in 1684, as she was another of Mlle Béjart's roles, the prude Climène in the Critique de l'école des fermmes.

Apparently Mlle La Grange was not deemed suitable by Molière for the central role of Philaminte in Les femmes savantes, which was instead played en travesti by the actor Hubert. Roger Herzel argues that the role had been written originally for Madeleine Béjart and that her illness may account for the delay in producing the play. ${ }^{30}$ Although the role seems somewhat outside of Mlle Béjart's usual emploi, which did not include vieilles, it can be seen as a complement to her role a decade earlier in Les précieuses ridicules. Philaminte is an aging Madelon.

Although Molière does not seem to have perceived in Mlle La Grange sufficient power to sustain the leading role in a five-act verse play, he did create for her several months earlier the role that would solidify the emploi of the vieille in years to come. The Comtesse is central to the comic and satiric intentions of La Comtesse d'Escarbagnas, but the play is short and in prose. It is also idiosyncratic. Devised for a court entertainment to celebrate the second marriage of the king's brother, Monsieur, it created a certain continuity in a ballet made up of 'tous ces beaux morceaux de Musique et de Danse' [all the beautiful bits of Music and Dance] selected from earlier works by Molière and Jean-Baptiste Lully. ${ }^{31}$ The play also formed a frame for a Pastorale, now lost, supposedly an entertainment being offered by the Vicomte, a character in the Comtesse d'Escarbagnas, to the lady herself. Divertissements from Les amants magnifiques, Psyché, George Dandin, Le bourgeois gentilhomme, and so forth were offered before, between, and after the 'acts' of the comedy and the pastoral. The livret from the court performance shows how Molière divided his troupe between the comedy and the pastoral: Molière himself, the handsome young Baron, and the troupe's two leading ladies, Mlle de Brie and Mlle Molière, were assigned the pastoral, while the leading roles in the comedy were taken by La Grange, Mlle La Grange, and Mlle Beauval (unusually, as the jeune première).

Originally written for the court, the play's principal satiric target is the minor provincial nobility, eager to appear au courant with the fashions and manners of the royal court but sadly uninformed. The Comtesse, who exemplifies this rural gentry, has recently passed two months in Paris and has returned to Angoulême, a small city 275 miles southwest of Paris and near nowhere. Although she has a house in town, she is actually from the rural, 
landed nobility. Upset by impertinent claims of equality by the townspeople, she proclaims the necessity of subordination: 'ce qui me met hors de moi, c'est qu'un Gentilhomme de Ville de deux jours, or de deux cents ans, aura l'effronterie de dire qu'il est aussi bien Gentilhomme, que feu Monsieur mon mari, qui demeurait à la campagne, que avait meute de chiens courtants, et qui prenait la qualité de Comte dans tous les Contrats qu'il passait' [I was simply beside myself when a certain bourgeois 'Gentleman' with a two-dayold title, or a two-hundred-year-old title, it doesn't matter, had the effrontery to say that he was just as much a Gentleman as my late husband who lived in the country, kept hunting dogs, and signed his contracts with the noble title of 'count']. Her interlocutor Julie, an urbane marquise, not so subtly undercuts the Comtesse by mentioning several Parisian hôtels 'dont la mémoire doit être si chère' [that you must remember so fondly] (1.2). ${ }^{32}$ Playing on multiple meanings of the word, the hôtels she lists are not great mansions of noble families, but mere inns for travelers. The Comtesse swallows the bait.

As well as satirizing the know-nothing provincial, the play characterizes the Comtesse as a vieille coquette, easily duped by Julie and the Vicomte who use her as a cover for their own affair. She also keeps in play two local suitors, Monsieur Tibaudier, a poetaster and town councilor, and Monsieur Harpin, an irate tax collector. The agreeable Tibaudier does his best to court her in courtly style, while Harpin rejects her, declaiming that 'Monsieur le Receveur ne sera plus pour vous Monsieur le donneur' [Monsieur the TaxCollector will no longer be Monsieur the Tax-Payer], and that 'je ne suis pas d'humeur à payer les Violins pour faire danser les autres' [I am not going to pay the musicians so other people can dance] (1.8). From this and other information, we conclude that the Comtesse is either relatively impoverished or rather greedy or both. That her household seems to consist only of a peasant girl, a little boy, and a gardener suggests that the former is the case, as does her agreement to marry Monsieur Tibaudier at the end of the play, but she has apparently taken Monsieur Harpin for a pretty penny as well.

She treats her naive servants badly, threatening them when they are baffled by her efforts to use a court vocabulary. Her terror of being perceived as old is revealed by her treatment of her son. The Petit Comte, played originally by an adult performer, is paraded before the company to show off his knowledge of basic Latin grammar. ${ }^{33}$ She, of course, has no Latin and thus misunderstands her son's recitation of 'Omne viro soli quod convenit, esto virile. Omne viri ...', taking it to refer to the crude French 'vit' meaning penis. Certain that her 'beauté, jeunesse, et qualité' can inspire passion 
in any man, ignorant, self-absorbed, unbearably pretentious, and crude, the Comtesse d'Escarbagnas opens the gates to a growing number of vieilles to be created by the next generation of comic playwrights, many originated on stage by Mlle La Grange.

La Comtesse d'Escarbagnas opened in Paris on 8 July 1672 with a different interior play, a shortened version of Le mariage forcé with new music by Charpentier. According to the Registre kept that year by Hubert, it had the largest one-day attendance of any play that season: 687 people. ${ }^{34}$ After a relatively successful run - for July — of fourteen performances, $\mathrm{La}$ Comtesse entered the regular repertory and served as a companion play to various Molière comedies and then as a petit pièce with any number of longer plays including several tragedies. Over the years La Comtesse d'Escarbagnas has been one of the most frequently performed of Molière's comédie-ballets at the Comédie-Française, second only to Le bourgeois gentilhomme. Ironically, when the Comédie-Française revived it in 1992, Mlle La Grange's role of the Comtesse was played by a male actor en travesti. ${ }^{35}$

After Molière's death in 1673, some important members of the PalaisRoyal troupe moved to the Hôtel de Bourgogne; the survivors, including Mlle La Grange, merged with actors from the Marais and moved to the Hôtel Guénégaud. Mlle La Grange continued to perform her roles in La Comtesse and Les femmes savantes while adding a small role in Thomas Corneille's verse adaptation of Molière's Dom Juan, ou le festin de pierre. Other new roles that suited her growing emploi included Gargamelle, a sixty-yearold scatterbrained coquette in Montaubon's Panurge, Madame de Grosbois, a 'diablesse de vertu' in Champmeslé's La Bassette, and Madame Valtoquet in Rosimond's Le Voluntaire. The latter is an aspiring bourgeoise, a subcategory of the vieille that would become classic in the comic theatre of the 1680s and 1690s. In 1679, however, the plum role of a vieille, Madame Jobin in La devineresse by Jean Donneau de Visé and Thomas Corneille, went to Hubert. ${ }^{36}$

Hubert may have been the last of the French travesti actors, but it should be noted that neither he nor the playwrights whose characters he portrayed seem to have used travesti as a burlesque device. The images of Madame Jobin in a series of engravings that accompanied the 1680 publication of the play are not identifiable as a man costumed as a woman, nor is the image of Madame de Sotenville in the frontispiece of George Dandin, unlike the images of the 1630 farceurs. ${ }^{37}$ Although the characters played by Hubert were comic characters, the comedy did not rely on the presence of a man 
dressed as a woman as it did, for instance, in Alizon. Rather, Hubert seems to have been a plausible female impersonator whose roles could be and were played equally well by actresses.

In 1684, after the merger of the Hôtel de Bourgogne and the Hôtel Guénégaud into the Comédie-Française, the actors drew up a repertoire of plays to be performed in 1685 with their distribution. Hubert, although slated for retirement, still retained Madame Pernelle, Philaminte, Madame Jourdain, and a vieille, Thérèse, added to Molière's Dom Juan by Thomas Corneille. Those roles probably passed either to Mlle La Grange or to a newcomer, Mlle Desbrosse, who also played caractères. Mlle La Grange is included in the cast lists of none of the tragedies in the repertoire but in twenty-six of the forty-one comedies. She was to play en première eight of Molière's roles and en seconde another seven. Besides the roles she had originated (Georgette and Belise), she accumulated the two Frosines in L'Avare and Le dépit amoureux, the prude Climène in La critique, several servante roles where she understudied Mlle Beauval, and the travesti role of Madame de Sotenville shared with M. Beauval. In addition to playing the title role in Quinault's La mere coquette, she was en première as La Tante in Thomas Corneille's Le Baron d'Albikrac, first performed at the Hôtel de Bourgogne c 1667. This character was also seminal in the development of the vieille emploi. ${ }^{38}$ According to Lancaster, La Tante is a 'superannuated belle', somewhere around sixty, 'weary of widowhood, desiring a young husband, ready to believe that several men are in love with her, and letting slip no opportunity that may give her a mate'. ${ }^{3}$ She dresses oddly, in 'mitigated mourning', is easily duped, and is jealous of her young niece. Like La mère coquette, Le Baron d'Albikrac remained in the repertory of the Comédie-Française until the late eighteenth century.

Among the more recent caractères that Mlle La Grange had originated before 1684 was Madame de La Rente in Champmeslé's Les joüeurs (1683), unfortunately lost. However, the character's name, 'Mrs. Investment Income', indicates that she is a bourgeoise and probably aggressively ambitious. In Boursault's La comédie sans titre (1683), also known as Le mercure galant, Mlle La Grange played Madame Guillemot, who comes to complain that the periodical has treated her with too little respect. Finally, in Champmeslé's Ragotin she was Madame Bouvillon, a vieille coquette who pursues Le Destin, actor-hero of the play as well as of Scarron's famous Roman comique. Her other roles in the non-Molière comic repertory are small ones, mostly servantes. Unfortunately, although the repertory lists twenty-eight petites comédies, including La Comtesse d'Escarbagnas, no cast lists are included. 
In 1685 Hubert, the last of the travesti actors, retired, as did Raymond Poisson, who had played the masque of Crispin, and four of the troupe's twelve actresses, opening the way to a new configuration. The four female retirees were Mlle de Brie, Molière's favorite ingenue, still playing the teenaged Agnés in L'école des femmes at age fifty-five; Mlle Guyot, originally from the Marais, who had collected a variety of roles in both genres, mostly servantes; and Mlles Dupin and Dennebaut, the daughters of Montfleury. ${ }^{40}$ Mlle Dupin had a few important roles, including Elvire in Le festin de pierre, her sister only two roles, although earlier she had been celebrated in tragedy for jeunes princesses and in comedy for breeches roles. By 1684, however, although she was only forty-two, she was reduced to playing Mlle La Caverne, the heroine's actress mother, in Ragotin. Only Mlle de Brie needed to be replaced in the same emploi.

The order to dismiss Mlles de Brie, Dupin, and Dennebaut was received on 19 June 1684, when Mlle La Grange, who had been reduced to a quartershare at the time of the merger, had her half-share restored. Someone found her somewhat valuable. During the season that followed, while the dismissed actresses continued to play, various aspirants to their shares were auditioned. Mlle Desbrosses tried out in September as Clytemnestra in Boyer's Agamemnon, Hermione in Racine's Andromaque, and Émilie in Corneille's Cinna one reine and two jeunes princesses. On 3 November, however, she seems to have been introduced at Fontainebleau in La Comtesse d'Escarbagnas and accepted by the pouvoir. ${ }^{41}$ When she joined the troupe at the beginning of the following season, she brought a strong talent for caractères, especially for femmes intriguantes. She was joined by yet another actress, Mlle Du Rieu, who would specialize in confidentes and caracteres, making a total of three actresses available and apparently willing to play older women's comic roles. After the retirement of Mlle La Grange in 1692, the troupe added Mlle Du Rieu's daughter, Mlle Godefroy, who seems to have specialized in demimondaines of a certain age, and in 1695 Mlle Champvallon, who was noted for vieilles coquettes.

Playwrights took advantage of the presence of these actresses, creating roles like Olimpe in Les bourgeoises de qualité, Madame Josse in Les mots à la mode, Madame Grognac in Le distrait, and Madame Patin in Le chevalier à la mode. The playwright who made best use of his troupe of caracteres was Dancourt, an actor in the company, who found a way to cast them in a series of short plays with musical divertissements that kept the Comédie-Française from financial ruin during the annual royal vacation when the premiers and 
premières in tragedy and comedy were in residence at Fontainebleau for up to six weeks. But that is another story.

The transition in comedy from men en travesti to women specializing in older female characters was long and not always obvious. Most scholars of the seventeenth-century French theatre are happy to quote Pierre Corneille on his substitution of the suivante for the nourrice, mention Molière's use of Louis Béjart and Hubert en travesti, and leave it at that. Poor Mlle La Grange has been given short shrift as well. Usually described as ugly and untalented but a coquette nevertheless, her biographies show the typical confusion of actress and roles. ${ }^{42}$

For fans of male travesti, the Italian troupe continued until 1697 to feature burlesque travestis with several of the masques playing female characters. Their satirical targets are often the same as those found in plays written for the French troupe: rich old maids and widows looking for husbands, bourgeois wives trying to improve their status, false aristocrats, femmes intriguantes, vieilles coquettes, salon wannabes, and so forth. Some of the plays, like La coquette (1691), are veritable feasts of travestis. In most instances, however, unlike the French plays that feature caracteres, the Italian repertory calls attention to the fact that men are playing women, adding salacious dialogue and actions reminiscent of earlier farce.

In the seventy years between Corneille's early comedies and the end of the century, comedy changed — of course — as did society — of course. Among the differences was the sheer dominance of comedy in the fin de siècle period. Between 1635 and 1651, fifty-five comedies were published, twenty percent of the total number of plays. Between 1683 and 1697, however, 211 comedies appeared, or seventy-seven percent of the total.

This increase may well be related to the move of the court from Paris to Versailles in 1682. The 1680 merger that led to the founding of the Comédie-Française was designed to provide entertainment for the court about to be distanced from Paris. The enlarged troupe could maintain a traditional repertory of the plays usually requested by the court and a new repertory of society and character comedies by Baron, Champmeslé, Dancourt, Regnard, Dufresny, and so forth, tailored to the tastes of the Parisian commercial audience, increasingly wealthy, worldly, and bourgeois. ${ }^{43}$ As Georgia Cowart writes, 'a taste for the satire of manners began to dominate subject matter, and audiences demanded situations that reflected their own experiences, both personal and political'. ${ }^{44}$ This period was or appeared to be what Saint-Simon called 'un regne de vile bourgeoisie' when comedy imitated both the upward 
social and financial movement of the commercial class and Saint-Simon's attitude toward it. ${ }^{45}$ Classical comedy assumes a predictable world with known outcomes, but the late-century stage reflects a world in which appearance rules, class and rank are fluctuating and volatile, and everything that once was fixed is now unstable. According to Guy Spielmann the most significant dislocation was that of the family and marriage. The 'système monarchique, phallocratique et patriarcal' came under intense scrutiny, the influence of the Church was diminished, and the conventional 'amorous idealism' of classical comedy was replaced by a 'matrimonial realpolitik'. ${ }^{46}$ Female characters could no longer be classified simply as wives and daughters, suivantes and servantes. The roles women played in society and the roles they played on stage, though still conventionalized, were much more various. Important in the new comic vision were the manipulative femmes d'intrigues, the demimondaines seeking respectability, and the rich widows on the hunt for titles of nobility. The subgenre of village and suburban comedies also featured such women, showing Parisiennes traveling to the countryside for pleasure and sexual intrigue. Their male counterparts included rich but frugal bourgeois, lawyers and financiers, officers and bureaucrats, all at odds with the impecunious young blondins with an eye on the main chance. Spielmann identifies as iconic 'Mme Patin, veuve à millions aspirant à la noblesse, et son chevalier "à la mode", blondin du bel air qui vit de ses charmes, conte fleurette à la nièce et, pour plus de sûreté, laisse des espérances à une baronne sur le retour' [Mme Patin, millionaire widow aspiring to the nobility, and her handsome and fashionable young suitor who lives on his charms, flirts with her niece and, for more security, allows an aging baroness to have hopes]. ${ }^{47}$ Mme Patin was first played by Mlle La Grange and then by Mlle Desbrosses. Unlike the often rather pathetic or peripheral vieilles and caractères that appeared before the late comedies of Molière, the caractères created by Dancourt and his colleagues are active, sometimes powerful, and often enjoy important amounts of stage time. Although they are satirized and occasionally burlesqued, they are not negligible. Nor were the actresses who played them.

Character actresses have been largely ignored by biographers and theatre historians, who have concentrated on celebrity-stars playing première roles. Yet the western repertory from the late seventeenth century to the present day is replete with roles that require impressive skills, from Madame Patin and Lady Wishfort to the dowager countess of Grantham and the cook Mrs. Patmore in Downton Abbey. Contemporary actor categories are now far more porous than they were in the era of the fixed emploi, and some character 
actresses like Meryl Streep or Glenn Close are also major celebrity-stars. The trajectory from Mlle La Grange's triumph as the Comtesse d'Escarbagnas to Mlle Streep's triumphs as Julia Child and Margaret Thatcher is a long and honourable one that warrants increased attention from theatre scholars interested in actors and acting.

\section{Notes}

1 Paul Scarron, Le roman comique (1651), ed. Yves Giraud (Paris, 1981), 74. This translation and all the others in this essay are my own.

2 For a history of early actresses in the French secular theatre, see my Women on the Stage in Early Modern France: 1540-1750 (Cambridge, 2010), 59-61, 78-9.

3 For information about French farces see André Tissier, Recueil de farces, 1450-1550, 13 vols (Geneva, 1986) and Farces françaises de la fin du moyen-âge, 4 vols (Geneva, 1999). See also Bernard Faivre, Répertoire des farces françaises: Des origines à Tabarin (Paris, 1993).

4 Ibid, 93-4.

5 For a fuller study of how the reputation of the actress developed see Scott, Women on the Stage.

6 Georges de Scudéry, La comédie des comédiens, ed. Joan Crow (Exeter, 1975), 1.3.

7 Michel Gilroy and Jean Serroy announce a total of twenty; other authors come up with slightly different totals. See La comédie à l'âge classique (Paris, 1997), 43. See also Lebègue and Lazard, below.

8 See Raymond Lebègue, 'Tableau de la comédie de la Renaissance', Bibliothèque d'humanisme et renaissance 8 (1946), 278-344. Lebègue has included any mention he has found of the word 'comédie'.

9 Madeleine Lazard, Comédie humaniste au XVI siècle et ses personnages (Paris, 1978), 65.

10 Pierre Corneille, Euvres complètes, Georges Couton (ed.), 2 vols (Paris, 1980), 1.1284 .

11 Lancaster remarks that Du Ryer's Lisandre et Caliste first uses the term suivante to mean a female attendant. H.C. Lancaster, A History of French Dramatic Literature in the Seventeenth Century. Part I: The Pre-Classical Period, 1610-1634, 2 vols (New York, 1964), 2.484.

12 Samuel Chappuzeau, Le théatre français (np, nd), 73. Sisigambis was the mother of Darius, king of Persia, in Alexandre Hardy's Le mort de Daire, a play written before 1626. 
13 The author in his Advertissement important writes: 'And I can say with the same truthfulness, that in three performances that I produced [fait faire] in the best houses of Paris, \& before a great number of persons of quality $\&$ merit. ... I do not know if a young Advocat ... received some disgrace; but ... he complained aloud of his ears hurting from listening to bad verses badly spoken, and was scolded by a quantity of decent folk ... even though he was partly right: For nothing is flawless, as the common saying goes. But he should have considered that the performers were not professional Actors and that I do not make a profession of being a poet'. L.C. Discret, Alizon, ed. J.-D. Biard (Exeter, 1972), 6.

14 W.D. Howarth (ed.), French Theater in the Neo-Classical Era, 1550-1789 (Cambridge, 1997), 103.

15 Claude and François Parfaict, Histoire du théâtre français, 14 vols (New York, 1968), 8.81 .

16 Lancaster, History: Part III: The Period of Molière, 1652-1672, 2 vols (New York, 1964), 2.689.

17 Ibid.

18 Other female roles are the ingénue daughter, who could have been played by either Mlle de Brie or Mlle Molière, and a servant/femme d'intrigue, very much in the comic emploi of Mlle Béjart. One bit of evidence that confirms the casting of Mlle $\mathrm{Du}$ Parc is that the play was dropped from the repertory when she left the troupe in spring 1667 and only reprised in April-August 1668 for six performances, which were poorly attended. Registre de La Grange in Molière, Euvres complètes, ed. Georges Forestier with Claude Bourqui, 2 vols (Paris, 2010), 1.1083-90.

19 Jean Donneau de Visé, La mère coquette (Paris, 1666).

20 Philippe Quinault, La mère coquette (Paris, 1666).

21 August Jal, Dictionnaire critique de biographie et d'historie, 2nd edn (Paris, 1872), 1033.

22 His name appears in a hand-written cast list for Andromède, but without any record of a performance. See Virginia Scott, Molière: A Theatrical Life (Cambridge, 1990), $74-6$.

23 Le premier registre de La Thorillière, ed. Georges Monval (Paris, 1890), 26-38.

24 Molière himself was reimbursed for Pernelle's costume, suggesting that since travesti was outside an actor's usual emploi, the company would foot the bill for the drag. See W.L. Schwartz, 'Light on Molière in 1664 from "Le second registre de La Thorillière"', PMLA 56 (1938), 1064.

25 La Grange, Registre, in Molière, Euvres completes, 1.1038, 1056.

26 Casting for the first two is known from livrets prepared for court performances. See Molière, Euvres complètes, 2.510, 1044-5. The casting of Bélise is assumed from 
the Repertoire of 1684. See H.C. Lancaster, Actors' Roles at the Comédie Française (Baltimore, 1954), 40.

27 Molière, Euvres complètes, 2.1700.

28 In 1684 she was playing, for instance, Agrippine in Racine's Britannicus, Hermione in Racine's Andromaque, and Cléopatre (not that Cléopatre) in Corneille's Rodogune. Lancaster, Actors' Roles, 3, 5, 14.

29 Although her age is somewhat clouded in myth, according to J. Fransen, Les comédiens français en hollande au XVII' et au XVIII siècles (Paris, 1925), 200, she was born in 1647.

30 Roger Herzel, 'Problems in the Original Casting of Les femmes savantes', Actes de New Orleans, Francis L. Lawrence (ed.), Biblio 17, Papers on French Seventeenth Century Literature (1982), 215-32. Molière had received a privilège to publish it more than a year before it was introduced at the Palais-Royal on 11 March 1672.

31 Molière, Euvres complètes, 2.1039.

32 Ibid, 2.1027.

33 The performer who played Le Petit Comte at court is listed as 'le sieur Gaudon', while the performer of the lackey, Criquet, is listed as 'Finet'. The identity of neither of these performers is known. Molière, Euvres complètes, 2.1045.

34 W.L. Schwartz, 'Molière's Theater in 1672-1673: Light from Le Registre d'Hubert', PMLA 56 (1941), 397.

35 INA.fr.

36 According to the Mercure galant, on the occasion of Hubert's retirement: 'jamais Acteur n'a porté si loin les roles d'homme en femme'. Madame Jobin is included among his roles. Mercure galant, Avril 1685, 211-12. See Le gazetier universel, <http:// gazetier-universel.gazettes18e.fr/periodiques?page $=1$.

37 Jan Clark, The Guénégand Theatre in Paris (1673-1680). Volume III. The Demise of the Machine Play (Lampeter, Wales, 2007), 226-7, and Comédie-Française, Portfolio Molière (Paris, 1994), 18.

38 I am unable to speculate about the actress who originated these roles at the Hotel de Bourgogne. Whoever it was, she (or conceivably he) was not in the ComédieFrançaise troupe in 1684 .

39 Lancaster, History, Part III, 2.808.

40 An anecdote has it that when the troupe tried to replace her in the role shortly before she retired, the audience insisted on her, and she was fetched from her home and went on stage in her street clothes to satisfy them. P.D. Lemazurier, Galerie historique des acteurs du théâtre français depuis 1600 jusqu'à nos jours, 2 vols (Paris, 1810), 2.149. 
41 La Comédie-Française, Registre de La Grange (Paris, 1876), 340. La Grange writes: 'Le 3me November, Vendredy. — Iphigenie \& Escarbagnas. Mlle Dancourt, Du Rieu et Desbrosses ont joué à l'essay et ont esté receues pr Pasques prochain'. Mlle Dancourt was being tried as a première and would have played Iphigénie in Racine's tragedy. The other two roles may have been played by Mlles Desbrosses and Du Rieu, although one or both may have been played by a member of the troupe. As to the Comtesse, La Grange lists the twelve actors who went to Fontainebleau on that occasion, and Mlle La Grange is not among them, suggesting that Mlle Desbrosses was tried out in the role.

42 See entries for Mlle La Grange in Jal, 176, Lemazurier, Galerie, 2.273-4, and Georges Montgrédien and Jean Robert, Les comédiens français du XVII siècle. Dictionnaire biographique (Paris, 1981), 122.

43 For example, in 1681 the Comédie-Française offered sixteen plays at Fontainebleau between 29 July and 30 September. Fifteen were standards, one was new. At the end of Louis XIV's reign, with many new plays available in the repertory, the court saw only one, along with five of Molière's comedies and Racine's Les plaideurs. Paul F. Rice, The Performing Arts at Fontainebleau from Louis XIV to Louis XVI (Ann Arbor, 1989), 67, 114.

44 Georgia Cowart, The Triumph of Pleasure: Louis XIV and the Politics of Spectacle (Chicago, 2008), 152.

45 Quoted by Guy Spielmann, Le jeu de l'ordre et du chaos: comédie et pouvoirs à la fin de règne, 1673-1715 (Paris, 2002), 69.

46 Ibid, 418.

47 Ibid, 43. Reference is to Le chevalier à la mode by Dancourt (1687). 